Provided for non-commercial research and education use. Not for reproduction, distribution or commercial use.

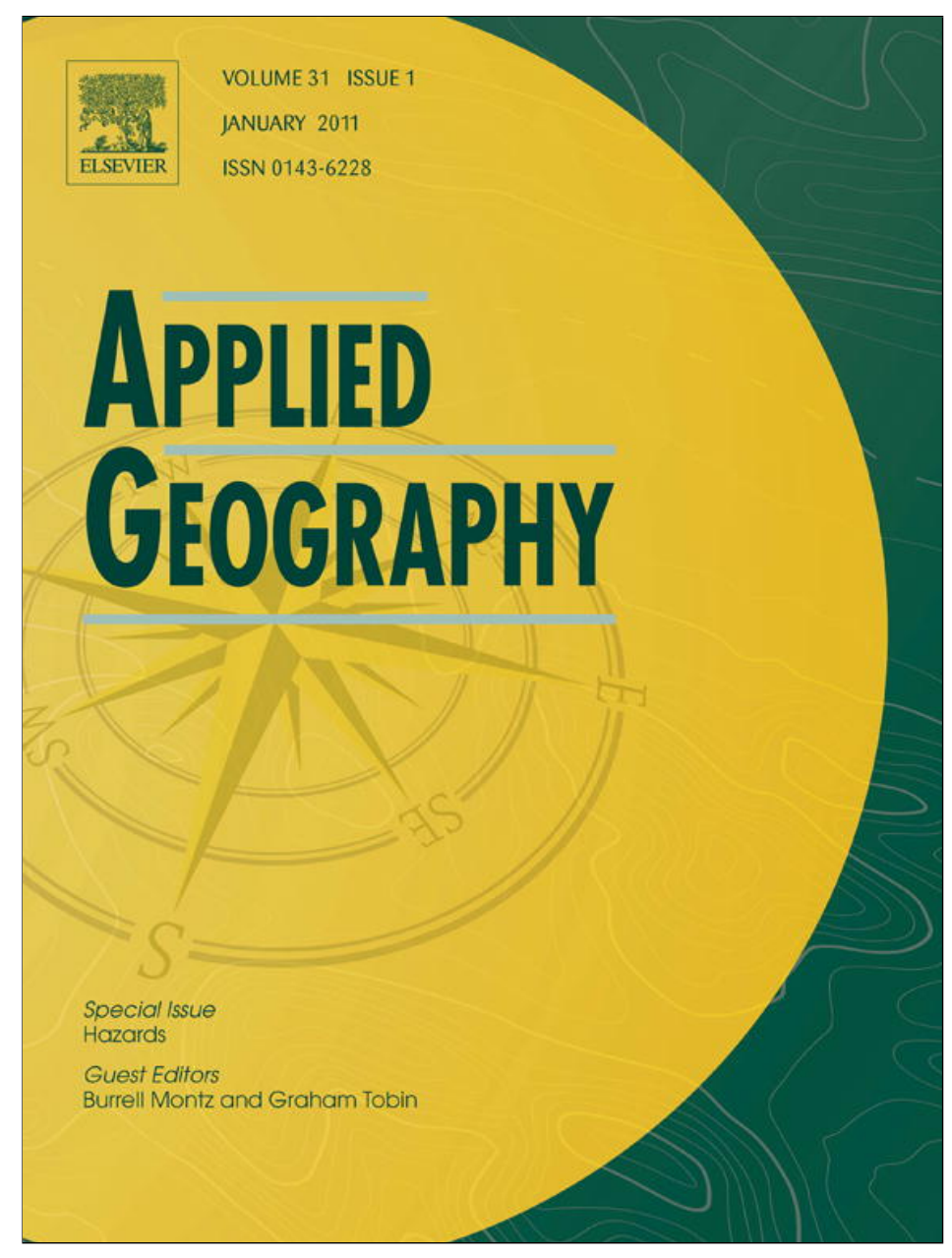

This article appeared in a journal published by Elsevier. The attached copy is furnished to the author for internal non-commercial research and education use, including for instruction at the authors institution and sharing with colleagues.

Other uses, including reproduction and distribution, or selling or licensing copies, or posting to personal, institutional or third party websites are prohibited.

In most cases authors are permitted to post their version of the article (e.g. in Word or Tex form) to their personal website or institutional repository. Authors requiring further information regarding Elsevier's archiving and manuscript policies are encouraged to visit:

http://www.elsevier.com/copyright 


\title{
Mapping temporally-variable exposure to flooding in small Mediterranean basins using land-use indicators
}

\author{
Ana M. Camarasa Belmonte*, María J. López-García ${ }^{1}$, Julián Soriano-García ${ }^{1}$ \\ Department of Geography, University of Valencia, Avda. Blasco Ibáñez, 28, 46010 Valencia, Spain
}

\section{Keywords:}

Maps of exposure

Risk

Floods

Hazard

Land use

\begin{abstract}
A B S T R A C T
This article deals with mapping exposure (or external vulnerability) to flood risk in two typical Mediterranean ephemeral streams: the Barranco de Carraixet and the Rambla de Poyo. The floodplains of both streams are within the metropolitan area of the city of Valencia (Spain's third largest city). Following the Mediterranean model, they are very fertile areas (with intense periurban and highly productive agriculture) which have recently absorbed the great urban expansion of the metropolis. Hydrologically these basins remain dry for most of the year, but become particularly dangerous during flash-flood events. They generate a risk pattern highly dependent on exposure since, in general, the hazard factor is very difficult to map, given the unpredictable nature of flash-floods.

This work constitutes a proof of concept based on simple estimators obtained from land uses. External vulnerability or exposure is evaluated as a function of economic land value and human exposure to hazard. Land value is directly taken from the cadastre whilst human exposure is indirectly estimated from the location of population in relation to time-activity profiles. The temporal dimension is introduced and three exposure scenarios have been mapped, related to different time periods: working days, nights, weekends and holidays.

The results show different patterns of exposure for each plain. In Carraixet floodplain exposure is greater at night and on weekends and holidays than during working hours, on account of the dominant agricultural and residential land uses. In the Poyo plain there are no major contrasts in absolute terms between day and night time, although spatial patterns of exposure vary from day to night: during the day, exposure is higher in industrial and commercial areas (around communication routes) whilst at night residential areas show more exposure.
\end{abstract}

(C) 2010 Elsevier Ltd. All rights reserved.

\section{Introduction}

Natural risk analysis has a spatial dimension which has been approached from the field of Geography (Díaz \& Díaz, 2002; Álvarez, 2005) with the aid of new spatial analysis techniques such as Geographical Information Systems. These techniques constitute one of the greatest contributions of Geography to risk analysis because they allow a spatial differentiation of risk and its components. Risk mapping can improve land use planning and management by establishing the most suitable location for each human activity (Bosque et al., 2005).

A map of natural risk is a synthesis map, based on the assessment and delineation of its components: hazard, exposure and vulnerability. In general, risk can be defined as the combination of

\footnotetext{
* Corresponding author. Tel.: +34 9638642 37; fax: +34 963864249.

E-mail addresses: ana.camarasa@uv.es (A.M. Camarasa Belmonte), maria.j. lopez@uv.es (M.J. López-García), jusogar@alumni.uv.es (J. Soriano-García).

1 Tel.: +34963864237.
}

hazard (the probability that a particular natural event reaches a specific threshold of intensity), exposure (people and property that may be adversely affected by the hazard) and vulnerability of the population exposed to such an event (ADCR, 2005).

While the components of risk are clear in theory, it is more complicated to map this risk, partly due to the difficulty involved in measuring exposure and vulnerability and partly because of the complexity entailed in specifying its spatial distribution. Up to 1950s the cartography of natural risks, and flooding in particular, was largely determined by the study of physical phenomena. Though the theory considered the human dimension, "without man there is no risk" (White, 1974), the applied studies focused on the delineation of floodable areas through the analysis of geomorphology, hydrology, hydraulics and historical events (Camarasa \& Bescós, 2004). These were no more than hazard studies, based on the behavior of the fluvial system during flood events. The human factor was only considered indirectly, as an active agent that intervened in the flow dynamics and generally through the structural measures used to control or mitigate floods (dams, river diversions, weirs...). 
As the twentieth century advanced and up to the present, it has been seen that technological development has not led to a reduction in the damage caused by flooding, and that the opposite has in fact occured with ever-increasing losses. In the twenty-first century the need to study both exposure and vulnerability as fundamental components of risks has been heightened by the International Strategy for Disaster Reduction, supported by a new focus directed towards the reduction of disaster through effective risk management. In the Hyogo Action Framework 2005-2015, governments from the whole world decided to take measures to reduce exposure and vulnerability to natural threats (UN/ISDR, 2005). From this perspective the physical event itself is considered a natural and external imponderable of risk (Birkmann, 2007) whilst the social and territorial vulnerability are where the real cause of disasters lies (Maskrey, 1993). An exaggerated interpretation of this thesis suggests that disasters are not natural but rather the result of a deficient social organization that leads to inadequate responses to extreme events in the physical environment (Díaz \& Díaz, 2002).

In this context, the only component of flood risk that is reasonably known is that of hazard assessment and the present challenge then lies in the establishment of mapping exposure and vulnerability. The complexity of the concepts themselves (given their social, economic, political and cultural dimensions) makes it difficult to find suitable indicators to be mapped.

First of all, the concepts are not clear and many authors have confused vulnerability with exposure, when actually they are two complementary components of risk (Alexander, 2000). Definition of exposure refers to elements at risk as: "an inventory of those people or artefacts that are exposed to a hazard" (UNDP, 2004). Vulnerability is a difficult concept to define due to its complexity and dynamism (Cutter \& Finch, 2007). Adger (2006) carries out a wide-ranging review of this term and concludes that this concept is a powerful analytical tool to describe states of susceptibility to harm, powerlessness, and marginality of both physical and social systems, and for guiding normative analysis of actions to enhance well-being through reductions of risk.

Birkmann and Fernando (2008) distinguishes at least six conceptual frameworks on how to systematise vulnerability: (1) the school of the double structure of vulnerability, that views vulnerability as the exposure to shocks and stressors and the ability to cope with these shocks (Bohle, 2001); (2) the conceptual frameworks of the disaster risk community, which separate vulnerability from coping capacities and exposure (Davidson, 1997; Bollin, Cárdenas, Hahn, \& Vatsa et al., 2003); (3) the analytical framework for vulnerability assessment in the global environmental change community, which, in a broader definition of vulnerability, encompasses exposure, sensitivity and response capacity (Turner et al., 2003); (4) the school of political economy, that emphasises the root causes and dynamic pressures that determine vulnerability and unsafe conditions (Wisner, Blaikie, Cannon, \& Davis, 2004); (5) the holistic approach to vulnerability assessment, which considers exposure/ susceptibility, socioeconomic fragilities and lack of resilience (Cardona, 2001; Carreño, Cardona, \& Barbat et al., 2004, 2005), and (6) the BBC conceptual framework which links vulnerability to the sustainable development discourse (Bogardi and Birkmann, 2004). As a consequence of its complexity there are divergent methods and epistemologies in vulnerability research. Nevertheless, the diversity and apparent lack of convergence is a strength and sign of vitality, rather than a weakness, of vulnerability research (Adger, 2006).

This paper is in keeping with the first framework (double structure of vulnerability), where exposure is equivalent to external vulnerability. According to Bohle (2001) vulnerability presents an external and an internal side. The internal side, considers the ability to cope, in reference to the capacity to anticipate, tackle, resist and recover from the impact of a hazard; while, the external side considers exposure to risk and shock. As indicated by Chambers (1989) the external perspective refers mainly to the structural dimensions of vulnerability and risk, while the internal dimension of vulnerability focuses on coping and action to overcome or at least mitigate the negative effects of economic and ecological change.

As such, exposure or external vulnerability itself is a purely spatial concept favorable to mapping analysis (Bosque et al., 2004). The problem lies in finding suitable indicators to estimate it. According to Downing (2004) exposure cannot be reduced to a single equation. The indiscriminate approach of selecting a mixed bag of indicators, normalising them and adding up the result into a single index should be avoided. Furthermore the estimation of the vulnerability and exposure should not be limited only to quantitative approximations, but should also cover qualitative aspects (Birkmann \& Fernando, 2008). It also seeks to discuss and develop all types of methods that may translate these abstract concepts into practical tools, classifications and comparative judgments to apply in the field (Birkmann \& Wisner, 2006). At the same time, indices should include dynamic aspects, because exposure and vulnerability change over space and time (Birkmann, 2005, Adger, 2006; Cutter \& Finch, 2007).

When taking all these limitations into account and the lack of information and the different scales at which this question could be approached, it is clear that we are working in a context where the methodological approximations are still at a fairly incipient stage. Indeed, cartography of vulnerability in a broad sense has consisted mostly of mapping elements of vulnerability (Downing et al., 2001; Yohe \& Tol, 2002; Zavala, 2002; O'Brien et al., 2004; Brooks, Adger, \& Kelly, 2005; Polsky, 2004; Luers, 2005; Cutter \& Finch, 2007), and even recognizing that these specific variables are only indirect indicators (Adger, 2006).

Birkmann (2007) carried out a comparative study of vulnerability indicators developed in three leading projects on both national and international scale: (a) the Disaster Risk Index, DRI, developed by the United Nations Development Program (UNDP, 2004); (b) the Hotspots Project, by the University of Columbia in collaboration with the World Bank (Dilley, Chen, Deichmann, Lerner-Lam, \& Arnold, 2005); and (c) The Americas Indexing Project, designed by the Environmental Studies Institute of the University of Colombia-Manizales, in cooperation with the Inter-American Development Bank (Cardona, 2005). The Disaster Risk Index (DRI) is based on mortality data and aims at the comparison of disaster risk between countries exposed to selected hazards (floods, tropical cyclones and earthquakes). The indicator has a global coverage but with nation-state resolution. The Hotspots Project develops a world map of hotspots showing where the risk of mortality and economic losses due to hazards of natural origin are greatest. Finally, The Americas Indexing Project is a more complex assessment, applied to 12 countries in Latin America, which approaches vulnerability and risk from four main indices, based on more than 50 indicators (exposure, socioeconomic fragility, lack of resilience, etc.).

Birkmann's comparative study shows that although each project was useful in its area of application, there are no clear, universally valid indicators. Far from closing the question, Birkmann asserts the need to continue research into methodological questions that will allow theoretical concepts to approach day-to-day reality.

Among the recommendations made by the Institute for Environment and Human Security (United Nations University), report No. 5/2006 (Birkmann \& Wisner, 2006), particular reference is made to the need to adapt methods to the specific features of each case and the necessity to combine both quantitative and qualitative information at an appropriate scale. In other words, it is recommended to design specific methods that, as a function of the information available and the characteristics of the area under study, are best adapted to the problem and its scale. 
It is in this context that this work attempts to map exposure or external vulnerability indicators in the floodplains of two typical Mediterranean streams: the Barranco de Carraixet and the Rambla de Poyo. They both form part of the metropolitan area of Valencia (Spain's third largest city). Their floodplains make up part of the Valencian coastal plain, one of the areas that have been most affected by growing urban expansion over the past century.

Both areas are representative of the model of a Mediterranean floodplain: consisting of sediments deposited by ephemeral streams (ramblas and barrancos) at times of maximum flow, typically flashfloods (Camarasa \& Segura, 2001). These are fertile plains, usually occupied by periurban, intensive and highly productive agriculture. They are also the most dynamic zones of the Mediterranean region, receiving and absorbing the great urban expansion that Mediterranean cities have experienced over recent decades. They generate a pattern of risk highly dependent on exposure as the hazard is generally very difficult to determine due to the unpredictable nature of flash-flood events and the fairly uniform socioeconomic status of the population (given the detailed scale of work).

This work proposes simple indicators based on land use for assessment and mapping and, indirectly, the exposure to flooding in small Mediterranean floodplains. A time factor has also been introduced, differentiating between working days and weekend/holidays on the one hand and between day time and night activities on the other.

\section{Study area}

Mediterranean ramblas and barrancos are fluvial systems with ephemeral streams, whose basins are small (several hundred square kilometres), with steep slopes, wide valleys and braided channel morphology. These systems, which are usually dry for most of the year, become particularly active during flood events. Flashfloods are especially rapid, violent, unpredictable and therefore dangerous (Camarasa \& Segura, 2001; Camarasa \& Tilford, 2002). These fluvial systems develop very fertile floodplains that often support highly productive periurban agriculture. In the last few decades they have suffered great change, creating a pattern of risk highly dependent on exposure.

The Barranco del Carraixet and Rambla de Poyo are two representative examples of Mediterranean ephemeral streams which flow into the sea to the north and south of the city of Valencia, respectively (Fig. 1). The Carraixet, together with other minor catchments, drains the region between the Palancia and Turia rivers, whilst the Rambla de Poyo covers the area between the Turia and the Jucar rivers, flowing into the Albufera de Valencia, a coastal lagoon (Camarasa, 1995). Both basins have generated floodplains which, combined with the Turia's floodplain, make up the Valencian coastal plain.

Historically the human occupation of this area was focused on the city of Valencia. Intensive agriculture developed around it,

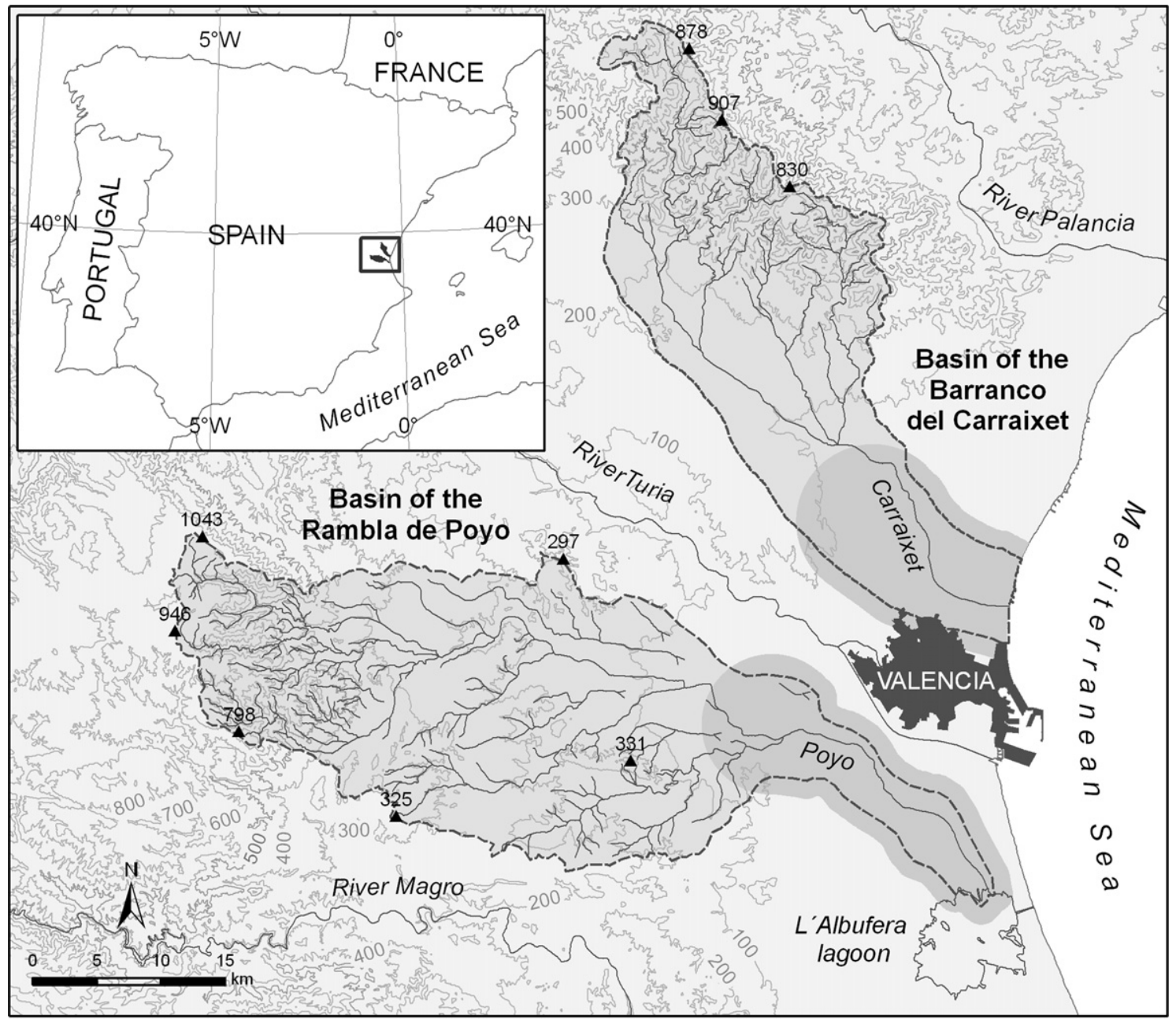

Fig. 1. Study area. 
mainly in the districts of the Horta Nord (covering the Carraixet plain) and the Horta Sud (the Poyo plain). As the city has grown it has progressively occupied neighbouring areas including the parts of these periurban belts within the metropolitan area.

The torrential nature of these ephemeral streams and their proximity to Valencia have produced serious flood problems, leading to the canalization of the final stretches of the river courses. However, far from solving the problem, the risk persists and has even increased, as urban expansion has continued.

Following the same trend experienced by Spain as a whole, major territorial changes occurred since the seventies. Huge areas of intensive farmland were converted into industrial areas and new residential districts. In the Poyo floodplain industrialization was particularly intense, especially in the furniture sector. The flooding of the city of Valencia in 1957 and the subsequent artificial diversion of the River Turia to the south, where it occupies part of the plain of the Rambla de Poyo, contributed to the changes in land use. Some of the more than twenty urban centres existing in the area merged into a single conurbation. The Carraixet plain experienced less industrial growth, allowing the agricultural sector to maintain some of its weight in the economy (Salom \& Albertos, 2006) and its hegemony of the landscape. Nowadays both plains make up a physically and functionally interrelated unit that is greatly dependent on the city of Valencia.

\section{Methodology}

The two floodplains under study initially show great homogeneity in terms of their dominant socioeconomic structure since they both are part of the metropolitan area of Valencia. Given this uniformity and the reduced extent of the study area, we propose a methodology based on simple land use indicators that allow the detection, at a detailed scale, of the points that are most exposed to a generalized flood. Considering that exposure refers to people and property affected by a natural disaster (ADRC, 2005), we follow the hypothesis that, faced with a similar flood level, the areas suffering the greatest losses would be related to high intensity residential use or high value of land. The exposure has therefore been estimated in relation to the intensity of people occupation of land and the economic land value. As an indicator of economic land value we have taken the cadastral value.

The level of human exposure has been determined from the intensity of land occupation by population (the places with higher density show higher exposure in case of flood). However, people do not have static locations but rather commute between their places of residence, work and leisure. Parrot and Stutz (1991) note the marked differences of uses between industrial and business districts and residential areas over the $24 \mathrm{~h}$ of a working day. In order to take into account the different degree of occupancy of the same space as a function of time of day (for instance a school will have maximum occupation during the day and minimum during the night), three human exposure maps were prepared for the cases of working day, weekend/holiday and night time.

Finally, a total exposure map has been estimated from the combination of the economic land value and human exposure, obtaining three exposure scenarios (working day, weekend/holiday and night time) (Fig. 2).

\section{Mapping economical land value}

The analysis of land-cover and land-use has been applied successfully in many studies to approach spatial estimation of economic losses to buildings and their contents (Ferrier \& Haque, 2003; Blong, 2003; Grünthal et al., 2006); in other words, to estimate exposure or external vulnerability. The methodological approaches range from very coarse indices (Ferrier \& Haque, 2003) to

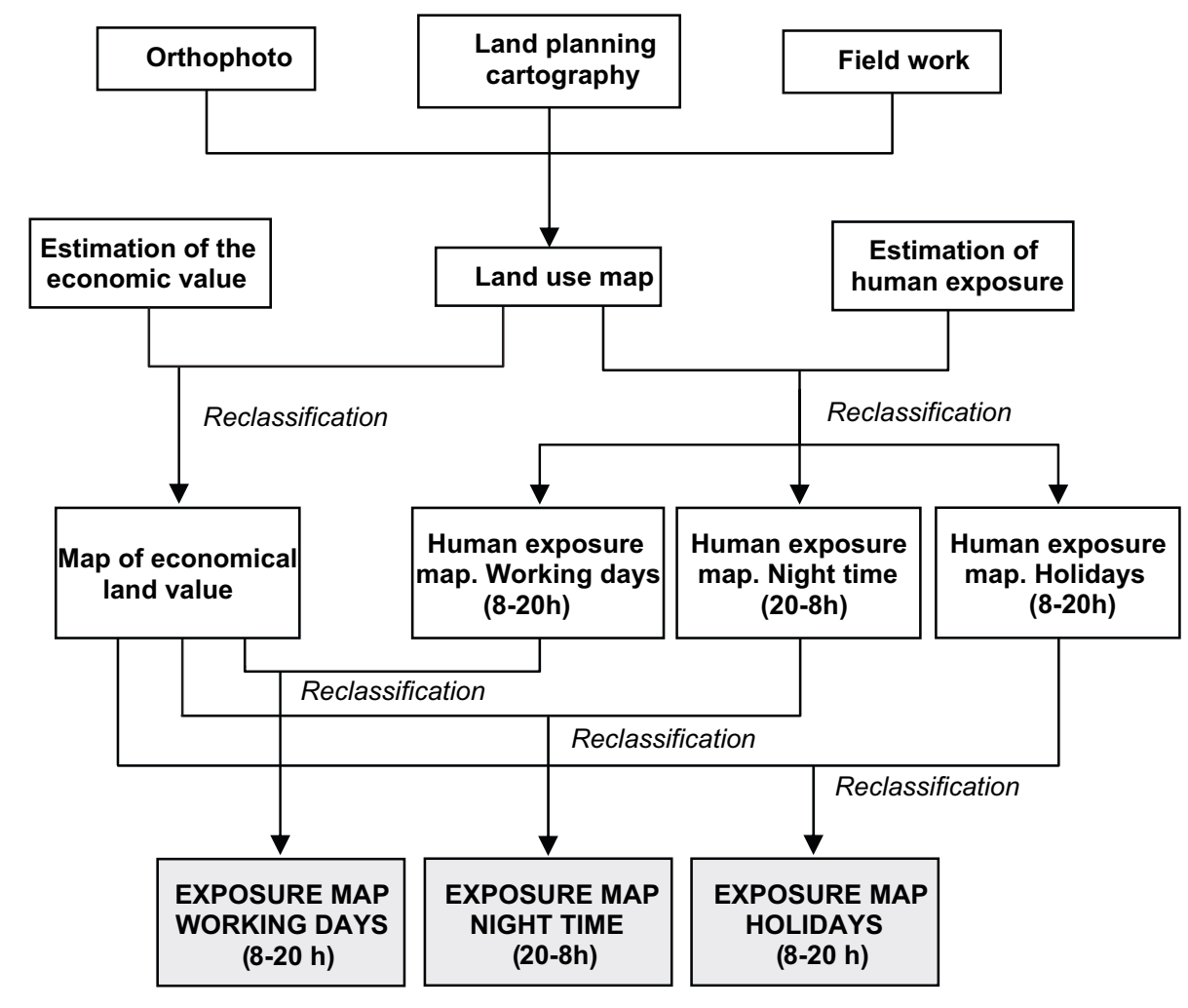

Fig. 2. Cartographic model. 
elaborate assessments, based on complex simulation tools (Collins, Grineski, \& Romo, 2009; Wood, 2009, Vinet, 2008; Tran, o'Neill, \& Smith, 2010). The choice depends on work scale and, specially, on data availability.

Mediterranean environments, due to historical anthropogenic pressure, not only show big transformations of land uses (easily detectable, for example, by remote sensing) but also a lack of social data spatially disaggregated, to carry on finer analysis (Maantay \& Maroko, 2009).

This paper proposes a simple indicator to evaluate the economical land value based on the land use maps, produced by interpretation of orthophotos, and the land use classification provided by the Conselleria de Medi Ambient (the regional environmental authority) according to the types shown in Table 1: residential, industrial, tertiary, public utilities, and agricultural and natural type.

Each type of use has a market value, directly related to the value of losses that would occur if it was affected by a natural hazard. To assess this economical value, different uses were evaluated with reference to the cadastre, as this is considered an official and consistent indicator that allows comparison between different uses (although we are aware that these values differ from actual market values).

The assignment of values was based on a previous analysis of the spatial behavior pattern of prices. In the case of agricultural uses, the five most representative subtypes of the region were considered: (1) citrus trees, (2) irrigated arable, (3) non-irrigated arable, (4) forestry and (5) pasture/fallow. The prices per hectare of each land crop class were compared for the different towns within the study area. This analysis revealed that prices were very similar for every class of agricultural use, allowing us to assign an average value for each agricultural class.

In relation to urban uses (residential, industrial, services) there was no representative average value for each class, but rather a great variability as much between municipalities as between the two floodplains. The specialized bibliography (Alonso, 1964; Mills, 1967; Muth, 1975; Chica, 1992; Royuela, Lambiri, \& Biagi, 2006; Cervelló, 2008) suggests a variation based on the inverse distance

Table 1

Human exposure assessment based on land use and time-activity profiles.

\begin{tabular}{|c|c|c|c|c|}
\hline \multirow[t]{2}{*}{ Land use types } & \multirow[t]{2}{*}{ Subtypes } & \multicolumn{3}{|c|}{ Level of human exposure } \\
\hline & & $\begin{array}{l}\text { Day } \\
(8-20 \mathrm{~h})\end{array}$ & $\begin{array}{l}\text { Night } \\
(20-8 \mathrm{~h})\end{array}$ & $\begin{array}{l}\text { Holidays } \\
(8-20 \mathrm{~h})\end{array}$ \\
\hline \multirow[t]{3}{*}{ Residential } & Low density & 2 & 4 & 4 \\
\hline & Medium density & 3 & 6 & 6 \\
\hline & High density & 4 & 8 & 8 \\
\hline \multirow[t]{2}{*}{ Industrial } & Low density & 2 & 0 & 0 \\
\hline & High density & 3 & 0 & 0 \\
\hline Tertiary & Tertiary & 4 & 0 & 0 \\
\hline \multirow[t]{10}{*}{ Public utilities } & Administration & 2 & 0 & 0 \\
\hline & Cemetery & 0 & 0 & 1 \\
\hline & Cultural & 2 & 0 & 4 \\
\hline & Educative & 8 & 0 & 0 \\
\hline & Green spaces & 1 & 0 & 2 \\
\hline & Sanitary & 8 & 8 & 8 \\
\hline & $\begin{array}{l}\text { Security } \\
\text { (e.g. Police) }\end{array}$ & 2 & 2 & 2 \\
\hline & Specials & 2 & 0 & 0 \\
\hline & Sportive & 2 & 0 & 4 \\
\hline & Non determined & 1 & 1 & 1 \\
\hline \multirow{8}{*}{$\begin{array}{l}\text { Agricultural } \\
\text { and natural }\end{array}$} & Irrigated arable & 0 & 0 & 0 \\
\hline & $\begin{array}{l}\text { Non-irrigated } \\
\text { arable }\end{array}$ & 0 & 0 & 0 \\
\hline & Citrus trees & 0 & 0 & 0 \\
\hline & Forestry & 0 & 0 & 0 \\
\hline & Rice field & 0 & 0 & 0 \\
\hline & Pasture/fallow & 0 & 0 & 0 \\
\hline & Lagoon & 0 & 0 & 0 \\
\hline & Fluvial channel & 0 & 0 & 0 \\
\hline
\end{tabular}

to financial centres (Central Business District or CBD). In order to test whether our area followed this model, relations between the prices of urban land and the distance to Valencia (the CBD of the area), were analyzed using as a variable the shortest distance to the centre of the city. Fig. 3 shows inverse relationships, with a high degree of correlation, between prices of the different urban land use classes and distance to Valencia, with different coefficients for each floodplain. In order to take into account this variation, the urban land price was estimated from the trend curve shown in Fig. 3, for concentric rings, separated from the centre of Valencia every $2 \mathrm{~km}$.

Finally, we should note that the map of economical land use value does not analyze the areas occupied by public utilities, since this constitutes a type of use whose value is not related to the area it occupies but rather responds to concepts of a different nature, related to strategic functions of risk management.

\section{Mapping temporally human exposure for different land use scenarios}

The people exposure map was also based on the land use map. As already mentioned, we considered three scenarios for land use as a function of time: working days, nights and holidays. It was assumed that between 8 a.m. and 8 p.m. the majority of the population is carrying out some activity outside the home (in the work place, studying, shopping, etc) whilst between 8 p.m. and 8 a.m. they are resting at home. The intensity of land use is also considered to be different on holidays and weekends, when most people do not have to work, go to their work place or place of study. It is then possible to establish the degree of human exposure in a particular space according to the theoretical level of the population density, which in turn depends on the time of day and on whether the day is a working day or not.

According to these criteria, three human exposure maps were prepared (working day, night time, and holiday), assigning values from 0 (minimum exposure) to 8 (maximum exposure) taking into account the intensity of land use by people at each time. Sanitary infrastructures (hospitals) have been considered separately. Given the peculiarity of its users (the sick, and low mobility people, not subject to work hours) they have been assigned the maximum value (8), independently of the time period.

Table 2 provides a sample of the allocation of exposure levels. On a work day, for example, the maximum level of exposure (8) is assigned to schools while the lowest levels correspond to rural uses. Residential, industrial and tertiary uses show medium levels of exposure (2-4). During the night the highest exposure (8) corresponds to high density residential areas, followed by medium and low density housing (levels 4-6). The lowest exposure (0) belongs to rural areas, as well as educational centres, industry and the majority of public infrastructures. On weekends and holidays the levels of exposure are similar to night time levels except for public spaces (parks, leisure and sports centres) where more people are concentrated.

\section{Maps of global exposure}

The global exposure maps consist on a qualitative assessment of economical land value (representing the potential losses in relation to land use) and human exposure to hazard (an indirect estimation of the density of people occupying a space in a given moment).

Even though the economical land value is a quantitative variable, the level of human exposure has been evaluated qualitatively from 0 to 8 , and the global exposure should also be assessed by a qualitative method. These kinds of methods are usually based on readily available data and on expert knowledge about the social features of 

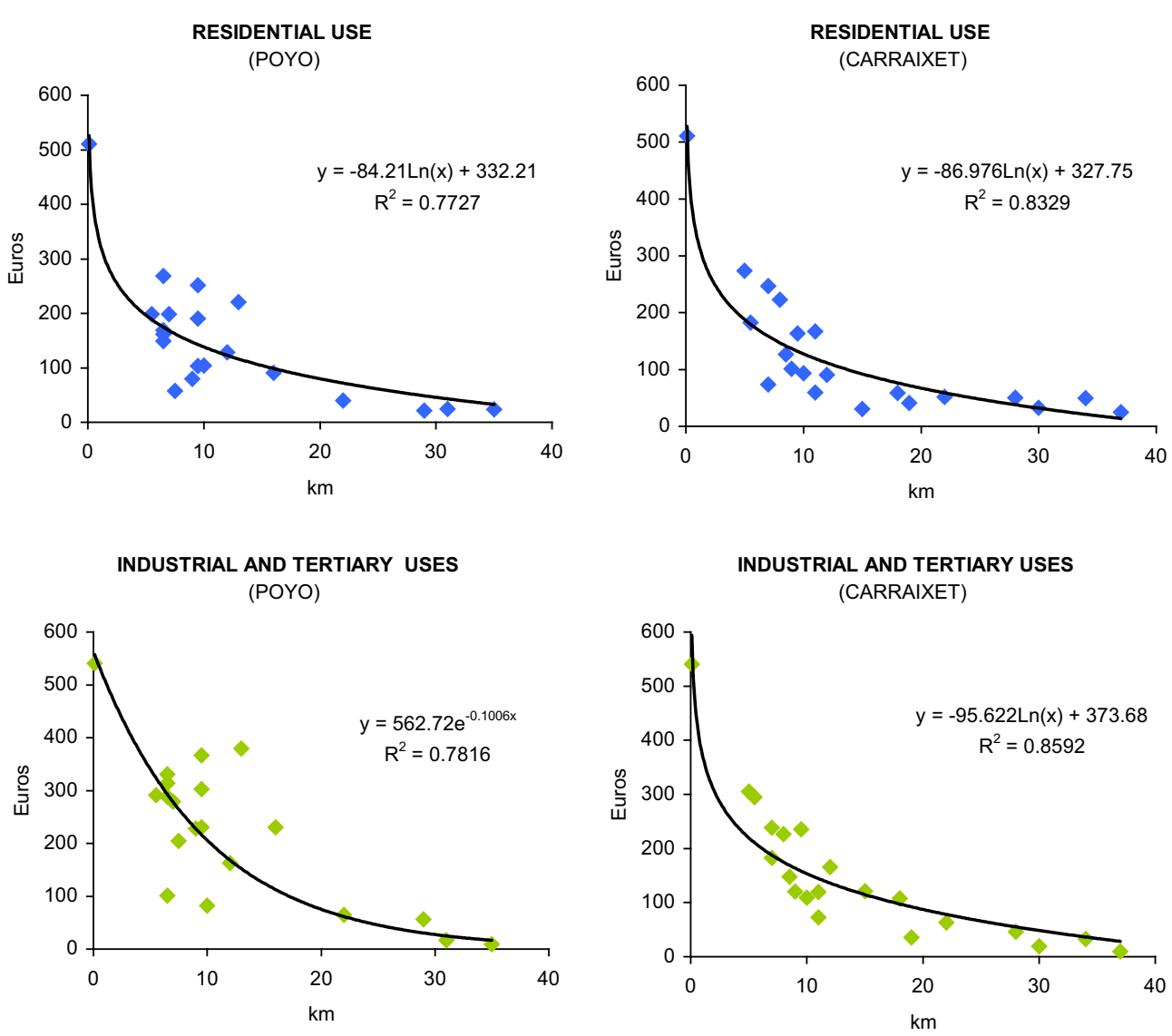

Fig. 3. Land use value ( $€ /$ ha) as a function of distance to Valencia: a) residential uses in the Poyo plain; b) residential uses in the Carraixet plain; $c$ ) industrial and tertiary uses in the Poyo plain and d) industrial and tertiary uses in the Carraixet plain.

the population, the hazard and the possible consequences on the territory (Ferrier \& Haque, 2003; Grünthal et al., 2006).

In this work, three global exposure maps were obtained by overlaying the maps of economical land value and the maps of human exposure for the three time scenarios. Table 2 summarizes the assignation of full exposure values, which were conducted by an expert panel. According to Tran et al. (2010), multidisciplinarity is necessary in this kind of expert panel. Different disciplines often use different meanings and concepts of vulnerability, which have led to diverse methods of measuring it. However, a global assessing should make to converge this knowledge in order to provide a qualitative scale of exposure to hazard.

In this work, the expert panel is integrated by experts on social sciences and natural sciences, specialized in human geography,

Table 2

Levels of global exposure.

\begin{tabular}{|c|c|c|c|c|c|c|c|c|c|}
\hline \multirow[t]{2}{*}{ Group } & \multirow[t]{2}{*}{ Land uses } & \multirow[t]{2}{*}{$€ /$ ha } & \multicolumn{7}{|c|}{ Human exposure level } \\
\hline & & & 0 & 1 & 2 & 3 & 4 & 6 & 8 \\
\hline A & $\begin{array}{l}\text { Non-irrigated arable, } \\
\text { forestry and pastures }\end{array}$ & $11-528$ & 1 & & & & & & \\
\hline B & $\begin{array}{l}\text { Irrigated arable and } \\
\text { citrus trees }\end{array}$ & $7,567-9,591$ & 2 & & 4 & 5 & 6 & 8 & 9 \\
\hline C & $\begin{array}{l}\text { Residential, industrial } \\
\text { and tertiary }\end{array}$ & $888,118-1,813,259$ & & 3 & 4 & 5 & 6 & 8 & 9 \\
\hline $\mathrm{D}$ & $\begin{array}{l}\text { Residential, industrial } \\
\text { and tertiary }\end{array}$ & $2,028,355-2,738,401$ & & 3 & 5 & 6 & 7 & 8 & \\
\hline E & Industrial and tertiary & $2,879,980-3,994,759$ & & 4 & 6 & 7 & 8 & 8 & 9 \\
\hline $\mathrm{F}$ & $\begin{array}{l}\text { Residential, industrial } \\
\text { and tertiary }\end{array}$ & $5,110,000-5,400,000$ & & 5 & & & & & \\
\hline
\end{tabular}

physical geography, flood risk, economic geography, land planning and emergency management. According to this panel, land values were grouped in six categories which were crossed with the eight levels of human exposure (Table 2). As a result of cross tabulations, in the area of study, 25 cases were obtained and evaluated by the experts panel in terms of full exposure, in a scale from 1 to 9 . Assessments have been carried out qualitatively, making an individual evaluation for every pair of categories. Linear functions have not been applied.

In total 10 exposure levels were established. Groups A and B show low exposure values as they include agricultural uses, with a low level of human exposure. Groups $C$ and D show higher economical land values (as they correspond to urban areas) and their level of exposure increase in relation to higher intensity of human land occupation. The higher levels of exposure are determined by the combination of groups $\mathrm{E}$ and $\mathrm{F}$ (which show the maximum economical land use values) and high levels of human exposure. Finally, level 10 of exposure does not appear in the table because it has been reserved for hospitals - at any time - and schools during working days.

\section{Results and discussion}

Figs. 4 and 5 show the exposure maps for working days and night time in the Carraixet and Poyo plains, respectively. The maps for holidays/weekends are not shown as they are very similar to the night time maps, except for leisure areas. Fig. 6 reflects the spatial changes in the exposure between night time and day time for working days. The proportion of changes of exposure between day 


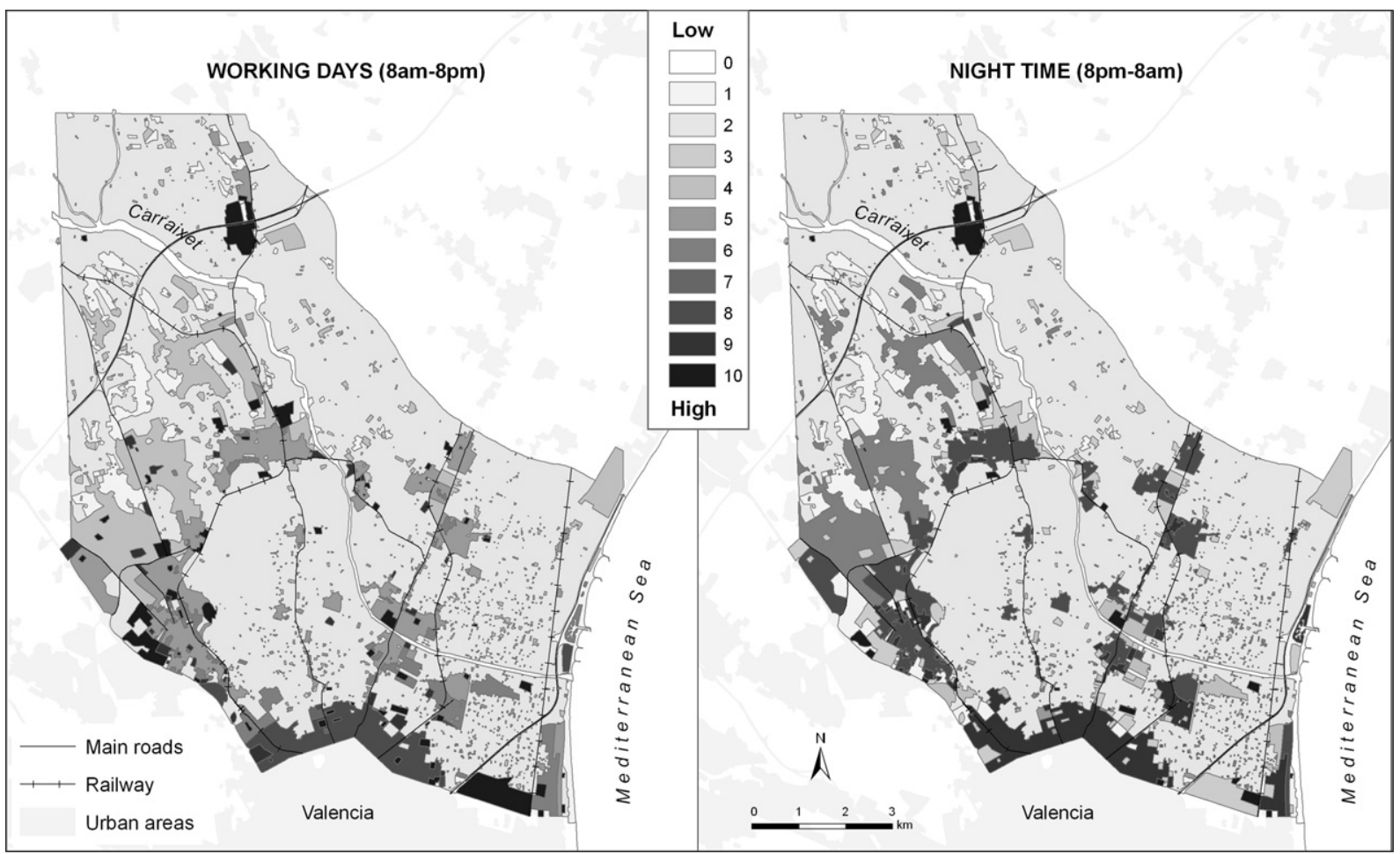

Fig. 4. Global exposure qualitative levels (from 0 to 10 ) for working days and night time. Carraixet floodplain.

and night has been estimated depending on the extent of the area which increases, decreases or maintains the exposure levels. At this point, it should be remarked that quantifications about how significant the changes are have not been carried out, because it is not advisable to detail quantitative changes in some variables whose quantitative value (exposure level) should be understood only as a ranking from highest to lowest sort.

Different behavior has been observed for each floodplain. The Carraixet floodplain shows (as well as the spatial change) an increase, in absolute terms, of the night time exposure in relation

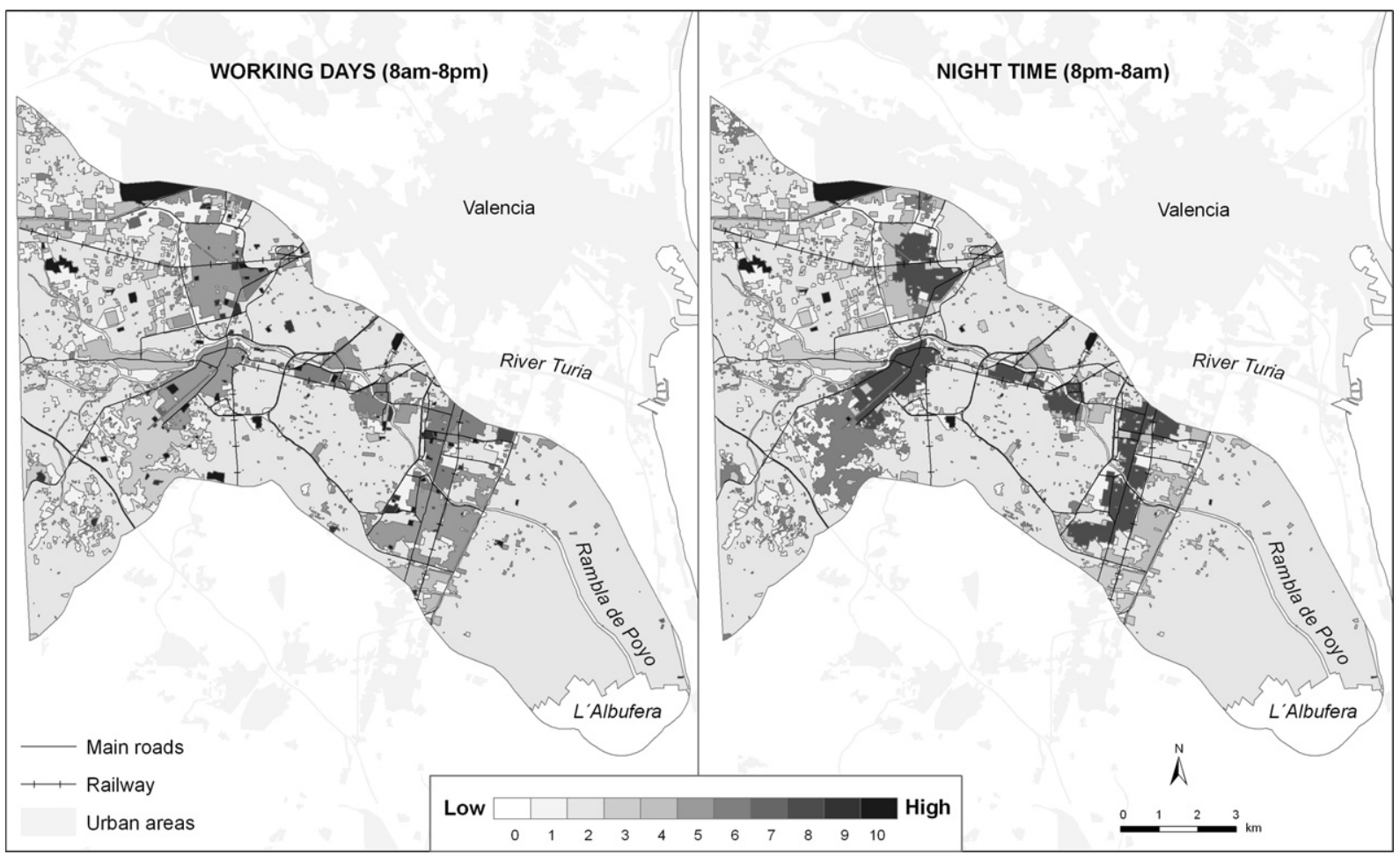

Fig. 5. Global exposure qualitative levels (from 0 to 10) for working days and night time. Poyo floodplain. 


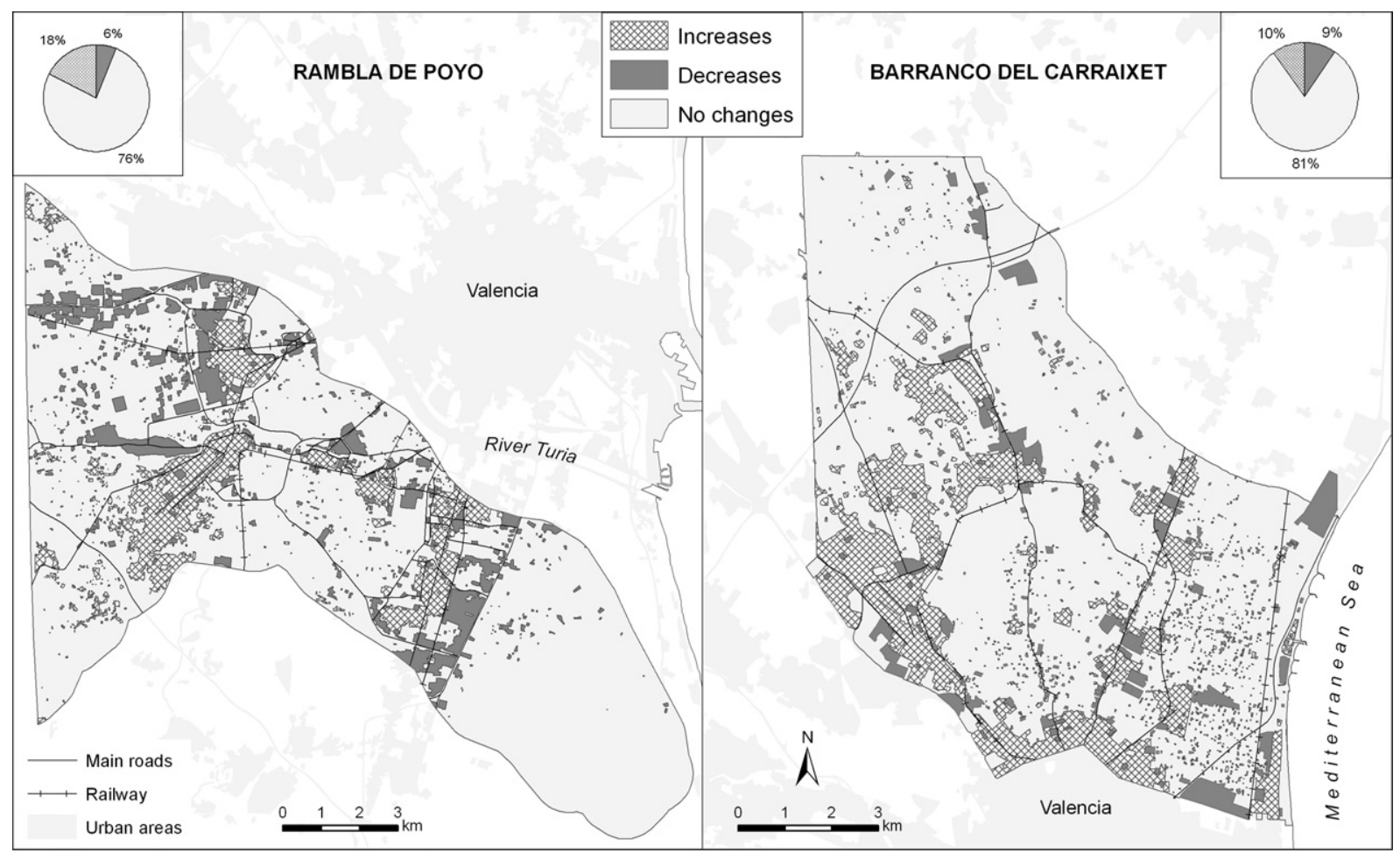

Fig. 6. Spatial changes in global exposure between night time and day time for working days.

to day time. The Poyo plain maintains more or less the same levels of exposure although a change in the spatial distribution of the most problematic zones has been observed between day and night time.

In the Carraixet plain, during the day, the most exposed areas were located close to the city of Valencia due to the high economical values of residential land. In general it is an agricultural plain without large industrial areas and most of the population works in the city of Valencia, outside the study area. However, this area has an important residential function, especially linked to its role as a dormitory area for the metropolis and secondary residence. This was shown by the $18 \%$ increase in exposure during the night that affects above all the urban nuclei; compared to the $6 \%$ decrease affecting the commercial and industrial areas.

The Poyo plain does not show changes, in absolute terms, in the area of the exposed zone between day and night (at night the exposure increases by $10 \%$ in the residential areas but reduces by $9 \%$ in the industrial and commercial zones). The plain partly reproduces the pattern for the Carraixet, concentrating highest values of exposure near to Valencia. Nevertheless, there is an increase during the working day in an important industrial area located in a corridor around the principal communication routes connecting Valencia with the south of the province. During the night, the highest exposure moves to a second line - to the west of this corridor - where the main residential areas are located.

This then reveals the different behavior of the exposure dynamic between the Carraixet and the Poyo floodplains. Although they belong to the metropolitan area of Valencia and have shared the process of urban expansion during the past 50 years, the land uses have evolved separately, with the Poyo plain greatly affected by the diversion of the Turia River following the 1957 flood (before this date it flowed through the city of Valencia). This canal, which crosses the Poyo floodplain, contributed to the rapid break up of the rural systems of the Horta Sud and the densification of industrial infrastructures, services and communications (Carmona and Ruíz,
2000). The Carraixet plain, however, maintained its agricultural structure till the end of the last century and the changes of land use have switched primarily towards the building of residential areas.

The different economic structure of these two spaces has subsequently led to different exposure patterns. The exposure of Carraixet is greater at night and on weekends than during working time, related to predominant agriculture and residential uses. In Poyo there are no big differences in absolute terms between day and night. However, the location of the exposed areas varies, being associated during the day with industrial and commercial estates (around communication routes) and concentrated in residential areas during the night.

Exposure mapping using indicators based on land use has been shown to be useful because it is simple and easy to apply and adapt to any area. It is based on easily available data and combines quantitative and qualitative estimates. This methodology is very flexible because it allows local condition adaptations through qualitative interpretations assessed by a panel of experts familiar with the territory. Furthermore, the inclusion of a time factor, related to working days, night time and weekends, adds a dynamic component to the cartography which is directly applicable to intervention strategies in case of disaster.

The methodology has great potential interest in the study of Mediterranean floodplains since, as already stated, these are environments where the risk is largely determined by exposure. At the same time, the unpredictability and scale of flash-floods in ephemeral streams makes the mapping of hazard difficult. Similarly, the increasing urban occupation of the plains - which are historically agricultural - means that the zones of risk are more and more dependent on the pattern of exposure.

In a broader context, this sort of cartography combined with a flood hazard map, can help decision makers to land planning. Reducing flood hazard in a torrential ephemeral stream is so difficult that the actions of land planning should be directed to reduce the vulnerability that, in the case of similar socioeconomic conditions of 
population, is equivalent to reduce exposure to hazard. In this sense, both strategies, risk mitigation (acting through the vulnerability) and risk management in time of emergency, may benefit from exposure mapping.

Finally, it should be noted that the ability to update this exposure map because, once known the keys for interpretation, it depends on land use update, that could be very fast and cheap using remote sensing technologies (Serra, Pons, \& Saurí, 2008; Wood, 2009; Pelorosso, Leone, \& Boccia, 2009). Likewise, changes in the behaviour of population (for example changes in the leisure spaces) or in the space functionality (for example a company closure) can be easily introduced through a reassessment of human exposure maps. The expert panel can even propose changes in assigning exposure values to take into account changes in the territorial management model (for example in relation to new strategies of risk management).

\section{Conclusions}

The methodology proposed in this paper has shown great potential to discriminate, from a qualitative approach, different levels of exposure to flood hazard in Mediterranean ephemeral streams. The main virtue of the method is its simplicity and low demand for data as it is able to provide a map of exposure based on land use mapping. It is also a very flexible method because allows adaptations to different areas, through qualitative assessments by an expert panel who knows the territory and can interpret its features in terms of exposure to hazard. It is particularly interesting in the case of Mediterranean environments since there is a generalized lack of data and a high human pressure over the land. Furthermore the use of time factor (working days, nights and weekends) includes a dynamic component to the cartography which helps to decision makers for land planning and disaster management.

In the specific case of the floodplains of the study area, the tested methodology has been shown to be effective for differentiating the exposure patterns of each plain. The economical value of the land use revealed representative prices for every class of agricultural use in the whole area of study, whilst in the case of urban uses (residential, industrial and tertiary) an inverse relationship between the land value and the distance from the city of Valencia was applied.

The exposure maps have illustrated that, although the two floodplains form part of the metropolitan area of Valencia and have shared its process of urban expansion, the pattern of exposure is different as a result of the breakdown of rural systems in the Poyo plain following the construction of the new canal for the Turia River (which formerly flowed through the centre of Valencia), after the 1957 flood. The Carraixet plain has evolved towards a basically agricultural structure, showing dormitory and residential functions. The Poyo plain has developed a dense industrial structure around the main communication routes. As a result, the exposure in the Carraixet is greater at night and on holidays/weekends whilst in the Poyo plain the differences between day and night mostly affect the location of the exposure spaces, which are associated with industrial and commercial areas during the day and are limited to residential areas during the night.

The authors are aware that the methodology presented in this paper does not measure the many different concepts of exposure or external vulnerability. Nevertheless, we consider that, given its simplicity, data economy, versatility and transferability, it can constitute a useful indicator. It may become a valid tool for the analysis of risk in cases, such as flash-floods, where the hazard is difficult to map and the spatial distribution of risk is greatly dependent on exposure.

\section{Acknowledgements}

This work was carried out thanks to funding from the Spanish Ministry of Education and Science, projects CGL2007-65368 and REN2003-07171, cofinanced by FEDER funds. The third author wishes to acknowledge the grant received from the Spanish National Programme for University Staff Training (FPU) awarded by the Spanish Ministry of Education and Science.

\section{References}

ADCR (2005) Total Disaster Risk Management - Good Practices. Available at: http://www.adrc.asia/publications/TDRM2005/TDRM_Good_Practices/PDF/ PDF-2005e/Chapter1_1.2.pdf.

Adger, W. N. (2006). Vulnerability. Global Environmental Change, 16, 268-281.

Alexander, D. (2000). Confronting Catastrophe, New Perspectives on Natural Disasters. Oxford/New York: Oxford University Press.

Alonso, W. (1964). Location and land use. Cambridge: Harvard University Press.

Álvarez, A. (2005). Sobre la evaluación de riesgos de desastres naturales y vulnerabilidad de la comunidad usando SIG. Editorial. Revista Internacional de Desastres Naturales, Accidentes e Infraestructura Civil, 5(2), 101-102, Available at: http://academic.uprm.edu/laccei/index.php/RIDNAIC/article/viewFile/95/94.

Birkmann, J. (2005). Measuring vulnerability. Report on the 1 st Meeting of the Expert Working Group of the United Nations University. Japan: Institute for Environment and Human Security (UNU-EHS).

Birkmann, J. (2007). Risk and vulnerability indicators at different scales: applicability, usefulness and policy implications. Environmental Hazards, 7, 20-31.

Birkmann, J., \& Fernando, N. (2008). Measuring revealed and emergent vulnerabilities of coastal communities to tsunami in Sri Lanka. Disasters, 32(1), 82-105.

Birkmann, J., \& Wisner, B. (2006). Measuring the un-measurable. The challenge of vulnerability. Source No. 5/2006. Bonn: United Nations University-Institute fo Environment and Human Security. Available at: <http://www.ehs.unu.edu/file. php?id=212>

Blong, R. (2003). A new damage index. Natural Hazards, 30(1), 1-23.

Bogardi, J., \& Birkmann, J. (2004). Vulnerability Assessment: the First Step Towards Sustainable Risk Reduction. In D. Malzahn, \& T. Plapp (Eds.), Disaster and Society. From Hazard Assessment to Risk Reduction (pp. 75-82). Berlin: Logos Verlag Berlin.

Bohle, H. G., (2001). Vulnerability and Criticality: Perspectives from Social Geography. Update IHDP, Newsletter of the International Human Dimensions Programme on Global Environmental Change 2/2001. Available at: http://www. ihdp.uni-bonn.de/html/publications/update/update01_02/IHDPUpdate01_02_ bohle.html. Accessed 15 Apr 2009.

Bollin, C., Cárdenas, C., Hahn, H., \& Vatsa, K. S. (2003). Natural Disasters Network. Comprehensive Risk Management by Communities and Local Governments. Washington DC: Banco Interamericano de Desarrollo. Available at: http://www. gtz.de/de/dokumente/es-red-de-desastres-naturales.pdf.

Bosque, J., Díaz Castillo, C., Díaz Muñoz, M. A., Gómez, M., González, D., Rodríguez, V. M., et al. (2004). Propuesta metodológica para caracterizar las áreas expuestas a riesgos tecnológicos mediante SIG. Aplicación a la Comunidad de Madrid. Geofocus, 4, 44-78.

Bosque, J., Ortega, A., \& Espinosa, V. M. (2005). Cartografía de riesgos naturales en América Central con datos obtenidos de Internet. Documents d'Anàlisi Geogràfica, $45,41-70$.

Brooks, N., Adger, W. N., \& Kelly, P. M. (2005). The determinants of vulnerability and adaptive capacity at the national level and the implications for adaptation. Global Environmental Change, 4, 37-48.

Camarasa, A. M. (1995). Génesis de crecidas en pequeñas cuencas semiáridas: Barranc del Carraixet y Rambla de Poyo. MOPT-Confederación Hidrográfica del Júcar. 252 pp.

Camarasa, A. M., \& Bescós, A. (2004). Cartografia de áreas inundables: comparación entre mapas de peligro y mapas de inundaciones concretas. Riesgos Naturales y Antrópicos en Geomorfología, Vol. II, 25-36, VIII Reunión Nacional de Geomorfología.

Camarasa, A. M., \& Segura, F. (2001). Flood events in Mediterranean ephemeral streams (Ramblas) in Valencia Region (Spain). Catena, 45, 229-249.

Camarasa, A. M., \& Tilford, K. A. (2002). Rainfall-runoff modelling of ephemeral streams in the Valencia Region (Eastern Spain). Hydrological Processes, 16(17), 3329-3344.

Cardona, O. D. (2001). Estimación holística del riesgo sísmico utilizando sistemas dinámicos complejos. Barcelona: Universitat Politècnica de Catalunya. Available via. http://www.desenredando.org/public/varios/2001/ehrisusd/index.html.

Cardona, O. D. (2005). Indicators of disaster risk and risk management. Main technical report. IDB/IDEA Program of Indicators for Disaster Risk Management. Manizales: National University of Colombia.

Carmona, P., \& Ruíz, J. M. (2000). Las inundaciones de los rios Júcar y Turia. Serie Geográfica, 9, 49-70.

Carreño, M. L., Cardona, O. D., \& Barbat, A. H. (2004). Metodología para la evaluación del desempeño de la gestión del riesgo. Barcelona: Monografías CIMNE IS-51, Universitat Politècnica de Catalunya.

Carreño, M. L., Cardona, O. D., \& Barbat, A. H. (2005). Sistema de indicaciones para la evaluación de riesgos. Barcelona: Monografías CIMNE IS-52, Universitat Politècnica de Catalunya. 
Cervelló, R. E. (2008). Evolución del mercado inmobiliario en centros urbanos. Efectos de la política de intervención pública. Doctoral thesis. Departamento de Economía y ciencias sociales, Universidad Politécnica de Valencia. Available at: $<$ http://dspace.upv.es/xmlui/bitstream/handle/10251/3342/tesisUPV2904.pdf? sequence $=11>$

Chambers, R. (1989). Vulnerability, coping and policy. In IDS Bulletin, 20, 2. Brighton (England): Institute of Development Studies, University of Sussex. pp. 1-7.

Chica, J. M. (1992). Análisis de la estructura espacial del precio de la vivienda. El caso de la ciudad de Granada. Revista Española de Financiación a la Vivienda, 21.

Collins, T. W., Grineski, S. E., \& Romo, M. L. (2009). Vulnerability to environmental hazards in the Ciudad Juárez (Mexico)-El Paso (USA) metropolis: a model for spatial risk assessment in transnational context. Applied Geography, 29, $448-461$.

Cutter, S. L., \& Finch, C. (2007). Temporal and spatial changes in social vulnerability to natural hazard. no. 7. In B. L. Turner, II (Ed.), PNAS, Vol. 105 (pp. 2301-2306). Worcester, MA: Clark University, Available at: <www.pnas.org/cgi/doi/10.1073/ pnas.0710375105>.

Davidson, R. (1997). An Urban Earthquake Disaster Risk Index. The John A. Blume Earthquake Engineering Center, Department of Civil Enginering, Report No. 121. Standford University, Standford.

Díaz, M. A., \& Díaz, C. (2002). El análisis de la vulnerabilidad en la cartografía de riesgos tecnológicos. Algunas cuestiones conceptuales y metodológicas. Serie Geográfica, 10, 27-42.

Dilley, M., Chen, R. S., Deichmann, U., Lerner-Lam, A., \& Arnold, M. (2005). Natural disaster hotspots. A global risk analysis. Washington DC: The World Bank. Hazard Management Unit.

Downing, T. E. (2004). What have we learned regarding a vulnerability science?. In Science in support of adaptation to climate change. Recommendations for an adaptation science agenda and a collection of papers presented at a side event of the 10th session of the conference of the parties to the United Nations Framework Convention on Climate Change, Buenos Aires, 7 December 2004 (pp. 18-21), Available at $<$ www.aiaccproject.org/whats_new/Science_and_Adaptation.pdf $>$.

Downing, T. E., Butterfield, R., Cohen, S., Huq, S., Moss, R., Rahman, A., et al. (2001). Vulnerability indices: Climate change impacts and adaptations. In UNEP policy series. Nairobi: UNEP.

Ferrier, N., \& Haque, C. E. (2003). Hazards risk assessment methodology for emergency managers: a standardized framework for application. Natural Hazards, 28 (2/3), 271-290.

Grünthal, G., Thieken, A. H., Schwarz, J., Radtke, K. S., Smolka, A., \& Merz, B. (2006). Comparative risk assessment for the city of Cologne, Germany - storms, floods, earthquakes. Natural Hazards, 38(1-2), 21-44.

Luers, A. L. (2005). The surface of vulnerability: an analytical framework for examining environmental change. Global Environmental Change, 15, 214-223.

Maantay, J., \& Maroko, A. (2009). Mapping urban risk: flood hazard, race and environmental justice in New York. Applied Geography, 28, 111-124.

Maskrey, A. (Ed.). (1993). Los desastres no son naturales. Colombia, La RED: Red de Estudios Sociales en Prevención de Desastres en América Latina.

Mills, E. S. (1967). An aggregative model of resource allocation in a metropolitan area. American Economic Review, 85, 615-623.
Muth, R. F. (1975). Numerical solution of urban residential land use models. Journal of Urban Economics, 2, 307-332.

O’Brien, K. L., Leichenko, R., Kelkarc, U., Venerad, H., Aandahl, G., Tompkins, H., et al. (2004). Mapping vulnerability to multiple stressors: climate change and globalization in India. Global Environmental Change, 14, 303-313.

Parrot, R., \& Stutz, F. P. (1991). Urban GIS applications. In Maguire., Goodchild., \& Rhind. (Eds.), Geographical information systems. Principles and applications, Vol. 2 (pp. 247-260). New Cork: Longman.

Pelorosso, R., Leone, A., \& Boccia, L. (2009). Land cover and land use change in the Italian central Apennines: a comparison of assessment methods. Applied Geografphy, 29, 35-48.

Polsky, C. (2004). Putting space and time in Ricardian climate change impact studies: agriculture in the US Great Plains, 1969-1992. Annals of the Association of American Geographers, 94, 549-564.

Royuela, V., Lambiri, D., \& Biagi, B. (2006). Economía Urbana y Calidad de Vida. Una revisión del estado de conocimiento en España. Institut de Recerca en Economia Aplicada. Documents de Treball 2006/6.

Salom, J., \& Albertos, J. M. (2006). Industria y ciudad. El Área Metropolitana de Valencia. Industria y ciudad en España: nuevas realidades, nuevos retos. In R. Méndez, \& H. Pascual (Eds.), Cizur Menor (Navarra) (pp. 273-306). ThomsonCivitas, Estudios y monografías de economía.

Serra, P. Pons, X, \& Saurí, D. (2008). Land-cover and land-use change in a Mediterranean landscape: a spatial analysis of driving forces integrating biophysical and human factors. Applied Geografphy, 28, 189-209.

Tran, L. T., o'Neill, R. V., \& Smith, E. R. (2010). Spatial pattern of environmental vulnerability in the Mid-Atlantic region, USA. Applied Geography, 30, 191-202.

Turner, B. L., Kasperson, R. E., Matson, P. A., McCarthy, J. J., Corell, R. W., Christensen, L., et al. (2003). A framework for vulnerability analysis in sustainability science. PNAS, 100(14), 8074-8079.

UN/ISDR. (2005). Hyogo Framework for Action 2005-2015. Building the resilences of nations and communities to disasters.. Available at: $<$ www.unisdr.org $>$.

UNDP. (2004). Reducing disaster risk. A challenge for development. Global Report. New York: United Nations Development Programme. Available at $<\mathrm{http}$ //www. undp.rg/bcpr/disred/rdr.htm $>$.

Vinet, F. (2008). Geographical analysis of damage due to flash floods in southern France: the cases of 12-13 November 1999 and 8-9 September 2002. Applied Geography, 28, 323-336.

Wisner, B., Blaikie, P., Cannon, T., \& Davis, I. (2004). At Risk: Natural Hazards, People's Vulnerability and Disaster. London: Routledge.

White, G. F. (1974). Natural hazards. Local, national, global. New York: Oxford University Press.

Wood, N. (2009). Tsunami exposure estimation with land-cover data: Oregon and the Cascadia subduction zone. Applied Geography, 29, 158-170.

Yohe, G., \& Tol, R. S. J. (2002). Indicators for social and economic coping capacity: moving toward a working definition of adaptive capacity. Global Environmental Change, 12, 25-40.

Zavala, P. (2002). Análisis espacial de la vulnerabilidad sísmica aplicando SIG y teledetección: el caso de la ciudad de Arica. Tesis doctoral inédita. Departamento de Geografía, Alcalá de Henares, Universidad de Alcalá de Henares. 